日植病報 $44: 35-46$ (1978)

Ann. Phytopath. Soc. Japan $44: 35-46$ (1978)

\title{
クワ菱縮病新梢の葉柄篩部組織内に見出せる マイコプラズマ様微生物の微細構造
}

\author{
山田義男* ・長島久和子* ・井上金治**・小島 暁*** \\ Yoshio YAMAdA*, Kuwako NAGASHIMA*, Kinji INOUE** and \\ Satoru KoJIMA***: Ultrastructural Features of \\ Mycoplasma-like Organisms Found in the Phloem of \\ Petiole from Young Leaf Naturally Infected with \\ Mulberry Dwarf
}

\begin{abstract}
The present scanning and transmission electron microscopy (SEM and TEM) was undertaken in an effort to clarify the ultrastructural features of mycoplasma-like organism (MLO) in phloem tissue cells of petiole, using young leaf naturally infected with mulberry dwarf. SEM revealed the three dimensionality of the fibrillar meshwork in phloem tissue cells from the diseased petiole. However, the occurrence of meshwork of this type was not seen in cells from the healthy petiole. The characteristic meshwork consisted mainly of both straight and branching filaments among which rounded bodies could be discerned. The ultrastructure of sectioned MLO corroborated in several respects the observations made by SEM. TEM of thin sections showed that both rounded and filamentous organisms were bounded only by a unit membrane and seen to contain ribosome-like particles. Thus, the fibrillar meshwork structures which are seen in the SEM may correspond to "filamentous organisms" observed by TEM. A similar structure has, to our knowledge, not been found in other vascular tissues of yellows-diseased plants. When MLO colony was observed by SEM, three basic morphological forms were seen : (1) rounded form, presumably main body, approximately 200 to $300 \mathrm{~nm}$ in diameter, (2) elongated and irregular form, and (3) filamentous form, roughly $120 \mathrm{~nm}$ in width, emerging from the main body. Moreover, by SEM, a better visualization of the spatial arrangement and configurations of single organisms, as well as colonies, was observed. Our results with SEM showed this MLO associated with mulberry dwarf disease to be similar in gross structural features to the cultured large-colony-forming mycoplasmas studied by this method. Details of ultrastructural features of MLO are presented.
\end{abstract}

(Received October 26,1977)

緒 言

クワ萎縮病罹病新梢の茎葉節部組織におけるマイ コプラズマ様微生物（MLO）の所在様式は，土居ら 15）により透過電子顕微鏡（TEM）を用いて詳細に 調べられた。その後, 数多くの植物の萎黄叢生病類に ついて, 罹病植物の茥葉節部組織に MLO が多数見出
され, MLO が病原体として逐次確認された ${ }^{11,16,17,21,}$ 22,25,28,31)。以上は，いずれも超薄切片の TEM 観察に 基づくあのである。

一方, 近年になり無細胞培地（in vitro）に生育し た数種の動物のマイコプラズマが走查電子顕微鏡（ SEM）で観察され，その表面微細構造と多様な形状 が明らかにされた2,4,23,24,26)。しかし，SEMを用いた

* 群馬大学教育学部 Faculty of Education, Gunma University, Maebashi, Gunma 371, Japan.

** 群馬大学内分泌研究所 Institute of Endocrinology, Gunma University, Maebashi, Japan.

*** 群馬県虫業試験場 Gunma-Ken Sericultural Experiment Station, Maebashi, Gunma 371, Japan. 
細胞内（in vivo） に打ける MLOの表面微細構造之 MLO コロニーの微細立体構造はまだ明らかにされて いない。そこで，筆者らは SEM および TEM を併用 し, 罹病桑新梢の葉柄穊部組織の MLO の形状を観察 し，若干の新知見を得ることができたので，ここに報 告する。

本文に入るに先立ち，御教示を賜わった東京大学農 学部土居養二博士ならびに終始御援助をいただいた群 馬県蟇業試験場岡部光波場長に厚く御礼申し上げる。

\section{実験材料および方法}

供試材料は群馬県寔業試験場クワ園に自然発生した クワ萎縮病罹病一の瀬の新梢から若葉を採取し, その 葉柄を用いた。

本報では, 新梢の先端に近い若葉で, 葉柄の長さが 約 $1 \mathrm{~mm}$ のものを若い葉柄とし，その下にある若葉 で, 葉柄が $5 \mathrm{~mm}$ 前後に伸長したものを生長した葉柿 と表現する。供試葉は0.1M リン酸緩衝液, $\mathrm{pH} 7.2$, に $3 \%$ ヨ糖および $6.25 \%$ グルタールアルデヒドを含 む固定液で 4 C， 3 時間浸漬したのち, 液中でカミソ リの刃を用いて葉身と葉柄とに切断し，さらに 2 時間 継続して前固定を行なった。ついで, ベロナール酢酸 緩衝液, $\mathrm{pH} 7.4$, に $2 \%$ オスミウム酸を含む固定液で $0 \mathrm{C}, 1$ 時間, 後固定を行なった。

SEM 用試料 二重固定後, 試料はAndersonの 方法 ${ }^{1)}$ により，臨界点乾燥装置を用いて乾燥した。乾 燥した試料は銅の支持台に銀ペーストで貼付後, 試料 表面を C-Au で蒸着し，JSM-15 で観察した。凍結法 の場合には, 固定試料を70\%アルコールで脱水し, 冷 却ホルダにのせ液体窒素で凍結し, 試料を割断した。 ついで, 予備排気室内で試料表面の霜を昇華させ, 軽 く $\mathrm{Au}$ 蒸着を施し，ホルダごと試料をCryo-SEMの 鏡筒内に插入し，直ちに観察した。

TEM 用試料 二重固定後, 試料はアセトン系列 を通して脱水し, Epon 812 亿包埋し, 薄切ののち, 酢酸ウラニールおよびクエン酸鉛で染色し, JEM-100 C型電顕で観察した。なお, 対照の健全葉についても 全く同様に処理し観察した。

\section{観 察 結 果}

SEM による病徵観察＼cjkstart健全葉身の表側の表皮に は，ち密に配列した表皮細胞の上に大小の毛茸が散在 し，その間を葉脈が走っていた（図 1 ）。一方，罹病葉 身の表側の表皮は, 葉面に䝆縮を生じ, 表皮細胞の境 界は不鮮明で, 葉脈の陷没が顕著であった（図 2 )。し
かし，葉面に細菌や系状菌などは認められなかった。 生長した健全葉柄の横断面における節部付近を図 3 に示した。内皮上にはアミロプラストとともに苳酸不 灰の結晶が蓄積していた。穊部および皮層の細胞内に は，わずかにアミロプラストの存在が認められるにす ぎなかった。一方，生長した罹病葉柄の節部付近に は, 多量の分泌物が蓄積していた（図 4 ）。また，内 皮および皮層の細胞内にはアミロプラストが充満して いた。罹病葉に抢ける以上の症状は，いずれも従来の 光顕観察の結果とよく一致している ${ }^{20)}$ 。

若い罹病葉柄の横断面污打る穊部組織の内部微細 構造を調べるために，凍結法を用いて SEM で観察し た結果を図 5 および 6 亿示した。節部は穊管，伴細胞 および節部柔組織(節部柔細胞) からなり (図 5 ),乙れ らの細胞内には網目状の含有物が認められた。それは 穊管でもっとも多く, 続いて節部柔細胞に, 伴細胞て はわずかであった。なお, 健全葉柄節部の各細胞内に は，いずれもこの種の含有物は観察されなかった（図 3)。したがって, 網目状の含有物は細胞質そのものと は考えられず，扔そらく本病感染に由来して細胞内に 形成されたものと推測される。図 5 の節管の一つを拡 大してみると, 遊離して存在する大小の球状粒子（図 6 ，矢印）とと屯に錯綜したフィラメントからなる網 目構造がよく発達していた。大小の球状粒子の直径は 200〜800nm であった。また，乙れらの球状粒子とは 別に，フィラメント上にはさらに微小な粒子が多数付 着していた。そのほか, 約 $2 \mu \mathrm{m}$ の径を有する 2,3 個のアミロプラストが細胞壁に接して観察された（図 6 )。

若い罹病葉柄篩部の TEM 像 以上の SEM 像を 解釈するために，TEMを用いて若い罹病葉柄の断面 における節部組織の全体像を観察した。図 7 および 8 はともに同一切片上の節部を示したものである。両図 において, 各篩管では, 核はすでに消失し, 液胞膜が 消え液胞と細胞質との区別がなくなっている。また， 細胞壁に接してアミロプラストおよび退化したミトコ ンドリアなよ゙が観察された。このような節管内には大 小の球状粒子およびひも状粒子が多数存在していた。 これらの粒子の拡大を図 9 -11に示した。図 9 は標準 的大きさと思われる 150～300 $\mathrm{nm}$ の径を有する球状粒 子を示したものである。その形状および大きさからみ て, 土居ら ${ }^{15)}$ にって罹病桑茥葉の節管内に確認さ れた MLO 粒子と同様であると思われる。すなわち, 球状粒子には MLO の特徵とされる 2 層構造の限界膜 (矢印), DNA 繊維およびリボゾーム様顆粒 が認め 
られた。さらに，2分裂を行なっていると思われる MLO が観察された。罒10に液胞膜（矢印）が破壊 され, 液胞と細胞質との区別が不明瞭になっている部 分を示した。穊管内にはPープロテイン繊維, 電子密度 の高い顆粒ならびにさまざまな形状をした MLO が見 出された。また，液胞膜に接して退化したと思われる ミトコンドリアが存在していた。図11は不斉楕円形あ るいは鼣棒状の大形の MLO を示したものである。乙 れらの MLO の中には $1 \mu \mathrm{m}$ を超えるむのがあり，し ばしばブレブ (bleb) を伴っているのが認められた。 また，細胞壁に沿って小胞体が観祭された。

図 7 において, 丸で記された節管, 伴細胞执よび篩 部柔細胞の配置は，図 5 の SEM 像における記号を符 したそれぞれの 細胞の 配置と概小対応するあのであ る。したがって，図５の節管を拡大した図６のSEM 像に見られる遊離して存在する大小の球状粒子(矢印) は，TEM 像との対比から MLO 粒子と推定された。 節部組織において, MLO は節管についで節部柔細 胞に見出せた（図 8 )。穊部柔細胞は一般に大形で, 中心部は大きな液胞で占められ, 細胞壁に沿った細胞 質内にはミトコンドリア，小胞体および大きなデンプ ン粒を含むアミロプラストないしは色素体などが存在 している。MLOはこのような細胞質内に観察された。 節管に隣接する伴細胞は大きさむさまざまであり, 一般に細胞質に富み，核を持ち，液胞は少ない（図 $7,8)$ 。細胞質内にはミトコンドリア, 小胞体が多 く，大きなデンプン粒で占められたアミロプラストな ごを含んでいる。伴細胞は発生的には節管と同一の細 胞から由来するが, MLO 粒子の出現頻度はもっとも 低かった。図8 の丸で記された伴細胞では，退化した と思われる球状 MLO 粒子の集塊が見られた。図12は この伴細胞を拡大したものである。大きな核を有する 細胞質の一部がくびれるように液胞内へ突出し, その 細胞質内には細胞小器官は認められず, これに代って 約 $200 \mathrm{~nm}$ の径を有する多数の MLO 粒子の集塊が認め られた。集塊の直径は約 $2 \mu \mathrm{m}$ であった。

SEM による伴細胞の観察図13は若い健全葉柄 の縦断面における伴細胞の内部構造を示した SEM 像 である。TEM 像（図 7，8）との対比から，細胞内 に散在する大形顆粒はアミロプラスト, 小形顆粒はミ トコンドリアと考えられる。一方, 若い雀病葉柄の伴 細胞内（図14）には，アミロプラストおよびミトコン ドリアのほかに，健全葉柄の伴細胞内には見られなか った多数の小粒子からなる直径約 $2 \mu \mathrm{m}$ 前後の集塊( 矢印）が観察された。小粒子の形状は球形のもの, 偏
平のもの，あるいは短いひも状のフィラメントを派生 しているあのなどがあった。以上の観察結果と TEM 像（図12）との対比加ら，SEM 像（図14）に見られ る小粒子の集塊は MLOの微小コロニーと推定され た。

\section{生長した罹病葉柄の篩管内に}

\section{見られる MLO コロニー}

図15一18は, 生長した罹病葉柄の横断面における節 管の内部構造を示した SEM 像である。この時期の節 管は若い罹病葉柄の節管に比べると，かなり肥大伸長 しており，節管内では散在するアミロプラストを覆い かくすように網目状の含有物が充満していた（図15）。 アミロプラストの部分を拡大してみると, 網目構造は 無数の叉状に分枝したフィラメントおよび大小の粒子 から構成されていた（図16）。一方，このような節管 内を TEMで観察する之, 図19に示したように, P-プ ロテイン繊維の間に多様な形状をした無数の MLO が 充満していた。大小の球状 MLO 粒子の大きさは 150 〜300nm の径を有するあのが多かった。また，100〜 $150 \mathrm{~nm}$ の幅を有するフィラメント状 MLO が多数見ら れ，乙れらの中には先端が 2 叉状ないしは 3 叉状に分 枝したあの (知印) が認められた。各フィラメントの 先端はわずかに膨潤していた。図19の右上の写真は, 同一節管内の細胞壁に接したアミロプラストの部分を 示したあのである。図16のSEM 像に見られる叉状に 分枝したフィラメントの幅は70～100nmで，その間に 散在する標準的球状粒子の径は150～300nmであった。 これらの值は TEM 像からの測定値とほぼ一致した。 以上の観察結果加ら, SEM像に見られる網目構造は， フィラメントの幅に多少の差異はあるが, MLO コロ ニーと推定された。

図16の矢印で示した径約800nmの偏平な大形粒子に はブレブが認められた。図17は網目構造の一部をさら に拡大したもので，150～300 $\mathrm{nm}$ の径を有する球状あ るいは偏平な粒子からフィラメントが数本派生してい た。多数のこのような粒子の各フィラメントの 先端 は，2叉状ないしは 3 叉状に分枝を繰返しながら生長 するので，それらが互いに錯綜して網目構造を形成す るあのと考えられる。また，各フィラメント上には， ある間隔をおいて数個の径約 $70 \mathrm{~nm} の$ 微小粒子 (矢印) が付着していた。なお，図中の径約550nmの偏平な大 形粒子(二重矢印) は，さらにそれぞれが 250～300nm の径をむつ 4 つの subunits からなるような表面棈造 を呈していた。図18は200～300nm の径を有する標準 的 MLO と思われる球状粒子からなるコロニーをさら 
飞拡大したものである。これらの粒子の形状は，遊離 して単独で存在するあの，3〜 4 個の粒子が数珠状に 連なって存在するすの (矢印),さらには球状粒子の表 面にブレブを生じているすの，およびフィラメントを 派生しているむのなどがあり，きわめて多様であっ た。

\section{篩管における MLO の移行経路}

MLO が篩孔を経て移行することはすでに 報告されて いる ${ }^{16,21,28)}$ 。図20は, 若い䍜病葉柄の断面における隣 接する 2 つ篩管を示した TEM 像である。穊管内に はP-プロテイン繊維およびアミロプラストとともに, さまざまな形状の大小の MLO 粒子が観察された。 若い篩管の 細胞壁には径約 0.5 1.0 $\mu \mathrm{m}$ の 篩孔（矢 印）が形成され，節孔に接する細胞壁にはカロー ス（callose）の形成が見られた。節管の細胞壁には plasmodesmata がよく発達しているが, MLOの移 行経路は，その大きさから主として篩孔を経て行なわ れるものと思われる。MLO コロニーの微細立体構造 と穊孔との配置を明らかにするために, 凍結法で処理 した若い雄病葉柄と生長した罹病葉柄のそれぞれの横 断面における節管内部の SEM 像を図 21 および 22 亿示 した。図21は，前掲の図 6 の穊管の一部を拡大したも のであり，MLOコロニーの立休的網目構造および細 胞壁に形成された節孔の集まりである節板（sieve plate）がよく観察された。球状粒子は150～300nmの 径を有するあのが多く見られた。これらの粒子から は, 一般にひむ状の細いフィラメントが派生してい た。その幅は50〜120nm にわたり，かなりの变動が みられた。生長した睢病葉柄の節管内部を示した図 22の SEM 像は, 図19の TEM 像と対応するもので ある。MLOコロニーは200～500 nmの径を有する球状 粒子执よび100〜 $150 \mathrm{~nm}$ の幅をもつフィラメントから 成り立っていた。てれらの值はいずれあ TEM 像から の測定值とよく一致していた。眓の右下に2つの節孔 (矢印) が見られる。罒 21 と 22 とを比較すると, MLO の球状粒子の大きさと数およびフィラメントの幅に は，かなりの差異が認められる。このような差異は。 主として節管内における MLO の発育過程に伴う形態 変化によるものと推測される。すなわち, MLO は発 育が進むにつれ，球状粒子からひも状の細いフィラメ ントを派生し, やがてフィラメントの幅と長さが増大 するとともに叉状に分枝し，さらにその先端がそれぞ れ分枝を繰返しながら生長するものと考えられる。し かし, SEM像に見られるMLOコロニーの三次元的形 状はきわめて複雑であり, 以上の観察結果から MLO
の発育環を推測することは困難であった。

\section{考察}

最近，無細胞培地に生育した動物のマイコプラズマ および植物の MLO について，それらの表面微細構造 の研究が SEM あるいはネガティブ染色法, フリーズ ・エッチング法による TEM 抽よび位相差顕微鏡など を用いて行なわれている。

SEM による観察は主として動物のマイコプラズマ に関するものが多い。Boatmanら4) は液体培地に形 成された $M$. pneumoniae の直径数 $10 \mu \mathrm{m}$ に達する球 状集塊（spherules）が，フィラメント状細胞の網目 構造からなるととを観察している。また，Kammerら 23) 执よび Biberfeldら ${ }^{2)}$ は $M$. pneumoniae の発育 過程における形態変化を調べ，この細胞は球状からフ イラメント状を経て大形粒子に変化することを示し た。そして，発育が進みコロニーを形成するようにな ると，フィラメントの長さが增大するととあに分枝す るようになり，各フィラメントの上には数個の小粒子 (bulbous element) が見られるととを報告してい $ろ^{23)}$ 。Mayberry-Carsonら ${ }^{26)}$ は寒天培地に形成さ れた Thermoplasma acidophilum のコロニーを調 へ，一視野における細胞の大きさの変異と形態の多様 性を観察している。コロニーは平均約 $1 \mu \mathrm{m}$ の径を有 する球状細胞の集まりから形成されているが，その中 にはまれに $5 \mu \mathrm{m}$ に達する大形粒子が見出される。大 形粒子の表面構造加ら，乙の粒子はさらに $1 \mu \mathrm{m} の$ subunits からなるととを推測している。Klainer ら 24) は M. gallisepticum の球状粒子の表面加ら数個 のブレブが突出していることを報告している。以上の in vitroにおけるマイコプラズマ類の表面微細構造 の所見之，本報で観察された症病葉柄の穊管内に見出 せるin vivoに打りるMLOのそれとを比較すると。 本質的にはいずれ屯同様と思われる。

ネガティブ染色法, フリーズ・エッチング法あるい は位相差顕微鏡による植物の MLO の観察は, Corn stunt やカンキツの Stubborn などについて行なわ れ, 動物のマイコプラズマと同様に, その発育過程で 球状粒子加ら数本のフィラメントを派生しフィラメン 卜状（filamentous form）となり，発育が進むと叉 状に分枝する所見が得られている $5{ }^{5,6,8,9,10,12,13,14,29,32)}$ とくに Razin ら 29) 抢よび Coleら ${ }^{8)}$ は，カンキツの Stubborn の MLO は発育過程の一時期に運動性のあ るラセン状フィラメント (helical filament) の形態 をとるが，培養が進むと運動性を失い，フィラメント 
は分枝し，ブレブ（vesicular bleb）の数が増加する ことを観察している。図11の TEM 像に見られる棍棒 状の大形 MLO の形態は，Coleら ${ }^{9)}$ が Stubbornの MLO (Spiroplasma citri) の TEM像仙示したラセ ン状フィラメントの形態と近似している。しかし, 本 報ではSEMによりラセン状フィラメントを確認でき なかった。

動物のマイコプラズマに関して Freundt ${ }^{18)}$ は $M$. mycoides 老用い，基本小体から派生したフィラメン 卜はその上に鎖状に小粒子を形成し，2父状に分枝し た後フフィラメントの崩壊にとあない小粒子，すなわ ち新しい基本小体を放出すると考元, 増殖法の一様式 として提案している。罒17のSEM像において, 叉状 に分枝したフィラメント上に見られる数個の径約 70 $\mathrm{nm}$ の微小粒子はFreundt のいう新しい基本小体に符 合するように思われる。Boatman ら² は. felis の 分裂様式を調べ， 3 ないし 4 個の球状粘子が連鎖した あのから，やがて個々の粒子が分離して新しい個体に なることを推定している。図18に示したSEM 像の中 に, 同様な形態を示す球状粒子の連鎖を見ることがで きる。上述のように，SEM像に見られたクワ萎縮病 のMLO が多様な形態を示すととは，従来の超薄切片 法による TEM 像からは十分に解明されていなかっ た。このととは, MLOの発育環を決めるさいに考慮 されるべきととと思われる。

図12に示した伴細胞において，退化したMLO の集 塊を内包する細胞質が，くびれるように液胞中へ㔖出 していると想像される TEM 像は, 液胞の役割を考え る上で興味がある。近年, 植物細胞の液胞之動物細胞 のライソゾーム(lysosome) との類似性が注目されて きた ${ }^{700)}$ 。ライソゾームは大別すると，一つは自家 分解胞 (autolysosome) として, 他は食胞 (phagolysosome) として存在している。一方, Cocking ${ }^{7)}$, Hibiら ${ }^{19)}$ および Otsuki ら ${ }^{27)}$ は, 植物のプロトプ ラスト（protoplast）にウイルスを感染させると，ウ イルス粒子は液胞内に取り込まれ，大半の粒子が消失 するととを観察している。これらの知見は, 植物細胞 に捄いても, 液胞が一つの 1ytic compartment とし
て機能するととを示唆するあのと思われる。伴細胞が 穊管や穊部柔細胞に比べて, MLO の出現頻度が低い ととの理由の一つは, 㧍そらく細胞質に富む伴細胞内 に形成された液胞がMLOを分解する機能を有するの ではないかと想像される。

本報ではSEM による観察にさいして，固定試料を 臨界点乾燥法および凍結法を用いて処理した。両者を 比較すると, 臨界点乾燥法は MLO の表面微細構造の 観察に, 凍結法は MLO コロニ一の微細立体構造の保 持に良い結果が得られた。しかし，MLO 細胞の付属 構成物, たとえばブレブなどの微細構造の観察および MLO 粒子の直径などを 正確に 測定するには，SEM はTEMに及ばないと思われる。

\section{摘要}

クワ萎縮病の明瞭な病徵を示す一の瀬の䍜病新梢か ら若葉を採取し, その葉柄を用いて, 節部組織内に分 布する MLO の表面微細構造および MLO コロニーの 微細立体構造を, SEM おるよびTEMを併用して観察 した。

SEM を用いて穊部組織を観察すると, 篩管, 穊部 柔細胞, 伴細胞の順に, それぞれの細胞内には網目状 の構造が発達していた。網目構造は150〜300nm の径 を有する大小の球状粒子㧍よび叉状に分枝した約 120 $\mathrm{nm}$ の幅を有する多数のフィラメントから成り立って いた。SEMによる球状粒子の大きさおよびフィラメ ントの幅は, TEMによるMLO の測定結果とよく一 致するので, 網目構造はMLO コロニーと推定され た。MLOはその発育過程で, 球状粒子からフィラメ ントを数本派生し,さらに各フィラメントの先端は 2 叉状ないしは 3 叉状に分枝を絽返しながら生長するす のと思われる。したがって, このような粒子が多数存 在すると,フィラメントは互いに錯綜して網目構造を 呈するようになると考えられる。

SEM による表面微細構造の観点からみた，in vivo に打けるクワ萎縮病の MLO の諸形態は, in vitroで 生育した動物のマイコプラズマの諸形態と本質的には きわめて近似していた。

\section{引用文献}

1. Anderson, T. F. (1951). Trans. N. Y. Acad. Sci. Ser II, 13: 130-134.

2. Biberfeld, G. and Biberfeld, P. (1970). J. Bacteriol. 102: 855-861.

3. Boatman, E. S. and Kenny, G. E. (1970). Ibid. 101: 262-277.

4. Boatman, E. S. and Kenny, G. E. (1971). Ibid. $106: 1005-1015$. 
5. Bové, J. M., Saglio, P., Tully, J. G., Freundt, A. E., Lund, Z., Pillot, J. and TaylorRobinson, D. (1973). Ann. N. Y. Acad. Sci. 225 : 462-470.

6. Chen, T. A. and Granados, R. R. (1970). Science 167:1633-1636.

7. Cocking, E. C. (1970). Int. Rev. Cyt. 28:89-124.

8. Cole, R. M., Tully, J. G., Popkin, T. J. and Bové, J. M. (1973). J. Bacteriol. 115 : 367-386.

9. Cole, R. M., Tully, J. G., Popkin, T. J. and Bové, J. M. (1973). Ann. N. Y. Acad. Sci. 225: 471-493.

10. Daniels, M. J., Markham, P. G., Meddins, B. M., Plaskitt, A. K., Townsent, R. and BarJoseph, M. (1973). Nature $244: 523-524$.

11. Davis, R. E. and Whitcomb, R. F. (1971). Ann. Rev. Phytopathol. 9 : 119-154.

12. Davis, R. E., Worley, J. F., Whitcomb, R. F., Ishijima, T. and Steere, R. L. (1972). Science $176: 521-523$.

13. Davis, R. E., Whitcomb, R. F., Chen, T. A. and Granados, R. R. (1972). In A Ciba Foundation Symposium. Elsevier, Amsterdam. pp. 205-225.

14. Davis, R. E. (1974). In Proceedings, Third International Symposium on Virus Diseases of Ornamental Plants. (Lawson, R. H., et al. eds.) College Park, Md. pp. 289-302.

15. 土居養二・寺中理明 - 与良 清 - 明日山秀文(1967). 日植病報 33:259-266.

16. 土居養二・奥田誠一(1973). Shokubutsu Byogai Kenkyu, Kyoto 8 : 203-221.

17. 土居養二(1974).マイコプラズマ（佐々木正五ほか編）請談社, 東京 pp. 124-151.

18. Freundt, E. A. (1974). In Bergey' s Manual of Determinative Bacteriology, 8th ed., (Buchaman, R. E., et al. eds.) Williams \& Wilkins Com., Baltimore, pp. 929-\$55.

19. Hibi, T. and Yora, K. (1972). Ann. Phytopath. Soc. Japan 38 : 350-356.

20. 平井篤造 (1959). 植物ウイルス病学 南江堂, 東京 pp. 66-87.

21. Hirumi, H. and Maramorosch, K. (1973). Ann. N. Y. Acad. Sci. 225 : 201-222.

22. Hull, R., Horne, R. W. and Nayar, R. M. (1969). Science 224 : 1121-1122.

23. Kammer, G. M., Pollack, J. D. and Klainer, A. S. (1970). J. Bacteriol. 104 : 499-502.

24. Klainer, A. S. and Pollack, J. D. (1973). Ann. N. Y. Acad. Sci. 225 : 236-245.

25. Maramorosch, K., Shikata, E. and Granados, R. R. (1968). Trans. N. Y. Acad. Sci. Ser II. $30: 841-855$.

26. Mayberry-Carson, K. J., Roth, I. L., Harris, J. L. and Smith, P. F. (1974). J. Bacteriol. 120: 1472-1475.

27. Otsuki, Y., Takebe, I., Honda, Y. and Matsui, C. (1972). Virology 49 : 188-194.

28. Parthasarathy, M. V. (1974). Phytopathology $64: 667-674$.

29. Razin, S., Hasin, M., Ne' eman, Z. and Rottem, S. (1973). J. Bacteriol. 116 : 1421-1435.

30. Villiers, T. A. (1971). Nature $233: 57-58$.

31. Whitcomb, R. F. and Davis, R. E. (1970). Ann. Rev. Entomol. 15 : 405-464.

32. Wolanski, B. S. (1973). Ann. N. Y. Acad. Sci. $225: 223-235$.

$$
\text { 記 号 説 明 }
$$

$\mathrm{A}$ ：アミロプラスト, $\mathrm{B}:$ ブレブ, $\mathrm{cc}$ : 伴細胞, $\mathrm{co}$ ：皮層, $\mathrm{CW}$ : 細胞壁, en : 内皮, $\mathrm{ER}:$ 小胞体, $\mathrm{M}:$ : トンド

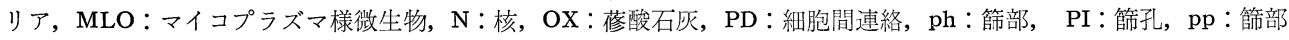
柔細胞, Pp：P-プロテイン, st：篩管, V : 液胞, ve : 導管, VS : 葉脈

図 版 説 明

第 1 図一第 6 図: SEM像による病徽。

図 1 : 健全葉の表側の表面構造。×80

図 2 : 罹病葉の表側の表面構造。 $\times 80$

図 3 : 生長した健全葉柄の横断面における篩部付近。 $\times 800$

図 4 : 生長した罹病葉柄の横断面における篩部付近。 $\times 800$

図 5 : 若い䍙病葉柄の横断面に扔ける篩部組織（凍結法）。 $\times 1,500$

図 6 : 前図の篩管の拡大（凍結法）。細胞内には大小の球状粒子（矢印）とともに錯綜したフィラメントからなる網 目構造が認められる。×5,000

第 7 図一第 8 図：若い䍜病葉柄の綐断面における篩部組織のTEM像。 
図 7 ：丸で記された篩管, 伴細胞および篩部柔細胞の配犆は, 図 5 のSEM 像における記号を符したそれぞれの細胞 の配置と対応する。 $\times 5,600$

図 8 : 丸で記された伴細胞の内部構造は, 図14つSEM像に示した伴細胞の内部構造之対応する。×5,600

第 9 図一第12戝：若い罹病葉怲の節管内に見られるさまざまな形状のMLOを示したTEM像。

図 9 : 標準的球状MLO粒子。2 層構造の限界膜（矢印）が認められる。 $\times 50,000$

図10: 液胞膜 (矢印) が破壊され, 液胞之細胞質との区別が不明膫になっている。篩管内にはP-プロテイン瀻維とと あに,フィラメント状のものおよびさまざまな形状をしたMLOが見られる。×50,000

図11：1 $\mu \mathrm{m}$ 超える大形のMLO。ブレブを伴うあのが見られる。 $\times 50,000$

図12: 図 8 の半細胞つ拡大。退化したMLOつ集塊を内包した細胞質が液胞中へ乫出している。 $\times 12,000$ 葑

第13図一第14図：伴細胞のSEM像

図13: 若い健全葉柄の縱断面における伴細胞の内部構造。 $\times 2,500$

図14: 若い犤病葉柄の縦断面における伴細胞の内部構造。矢印は多数の小粘子からなる集塊を示す。 $\times 2,500$

第15図一第18図：生長した痽病葉柄の横断面における穊管内の網目状のMLOコロニーを示したSEM像。

図15：笁管内にはアミロプラストが散在し，乙れらのアミロプラストを覆いかくすように網目状の含有物が充満して いる。 $\times 800$

四16：網目構造は大小の粒子とともに無数の叉状に分忮したフィラメントから成り立っている。×12,000

図17：球状粒子からフィラメントは数本派生している。フィラメント上には数個の微小粒子 (矢印) が付着している。 二重矢印は径約 $550 \mathrm{~nm}$ の偏平な大形粘子を示す。 $\times 24,000$

図18：標準的球状粒.于の集塊。矢印は 3〜 4 個の䊑子が数珠状に連なったあのを示す。 $\times 40,000$

第19図：生長した程病葉柄の縦断面における篩管内のTEM像。矢印は 2 叉状あるいは 3 叉状に分枝したフィラメント を示す。右上の写真は，同じ篩管内のアミロプラストの付近を示す。 $\times 20,000$

第20図：若い罹病葉柄の縦断面にお汀る隣接する 2 つの穊管を示したTEM像。矢印は篩孔を示す。 $\times 6,700$

第21図一第22図：穊管内のMLOコロニーの微細立.体構造と篩板を示したSEM像（凍結法）。

図21：若い䍜病葉柄の横断面における穊管。図6の一部を拡大したもの。×20,000

図22：生長した䍜病葉柄の横断面における穊管。矢印は篩孔を示す。×20,000 

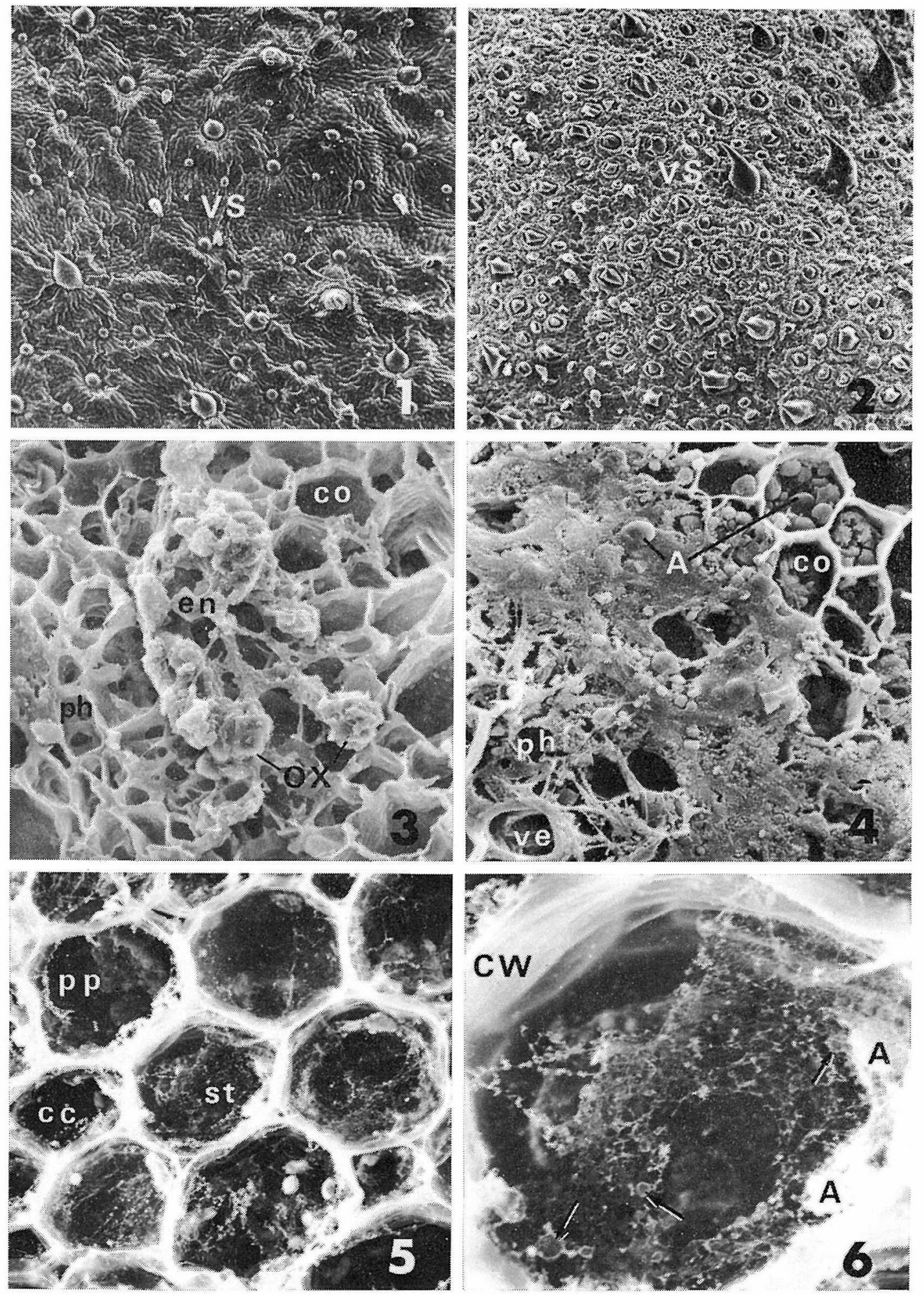


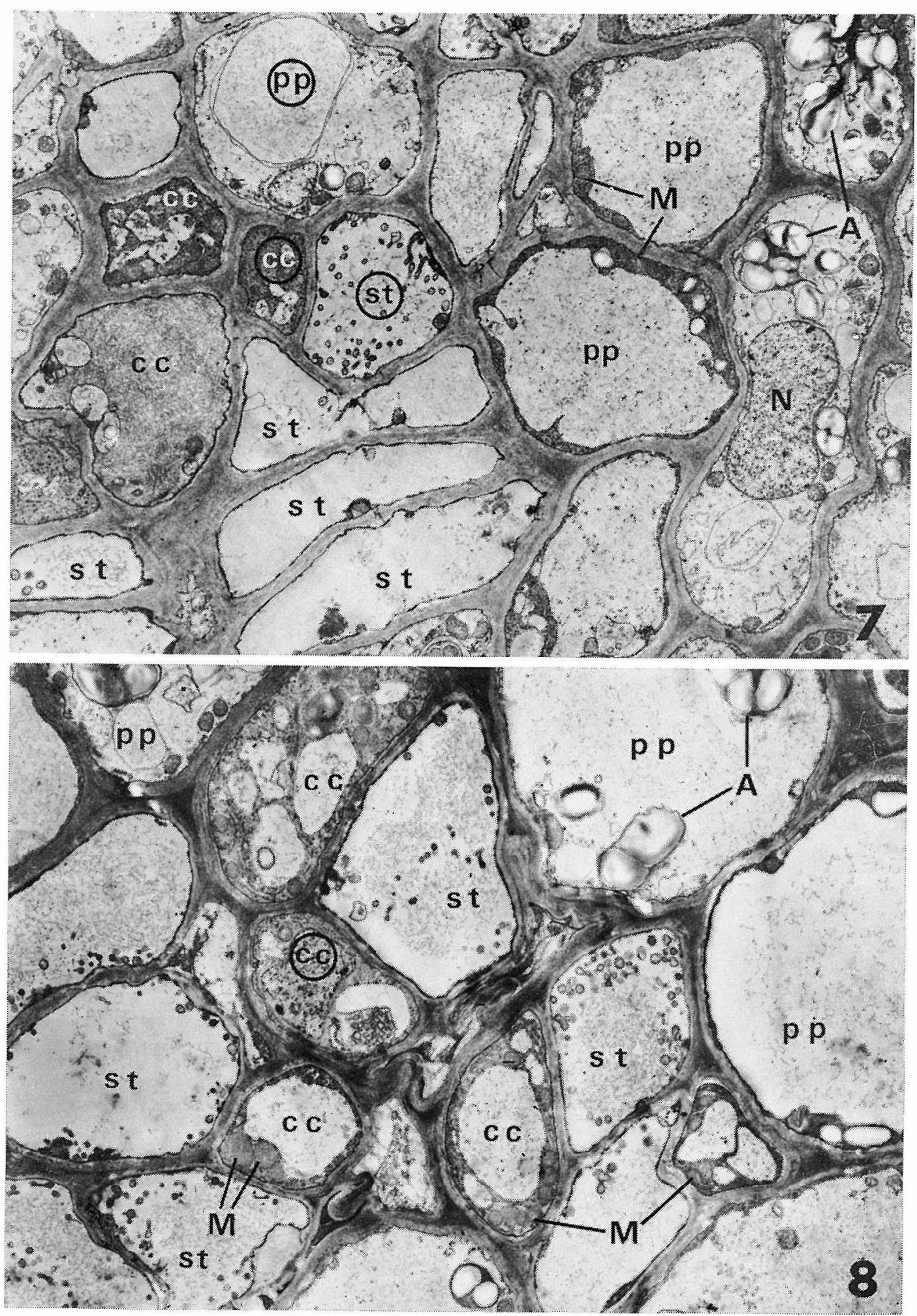



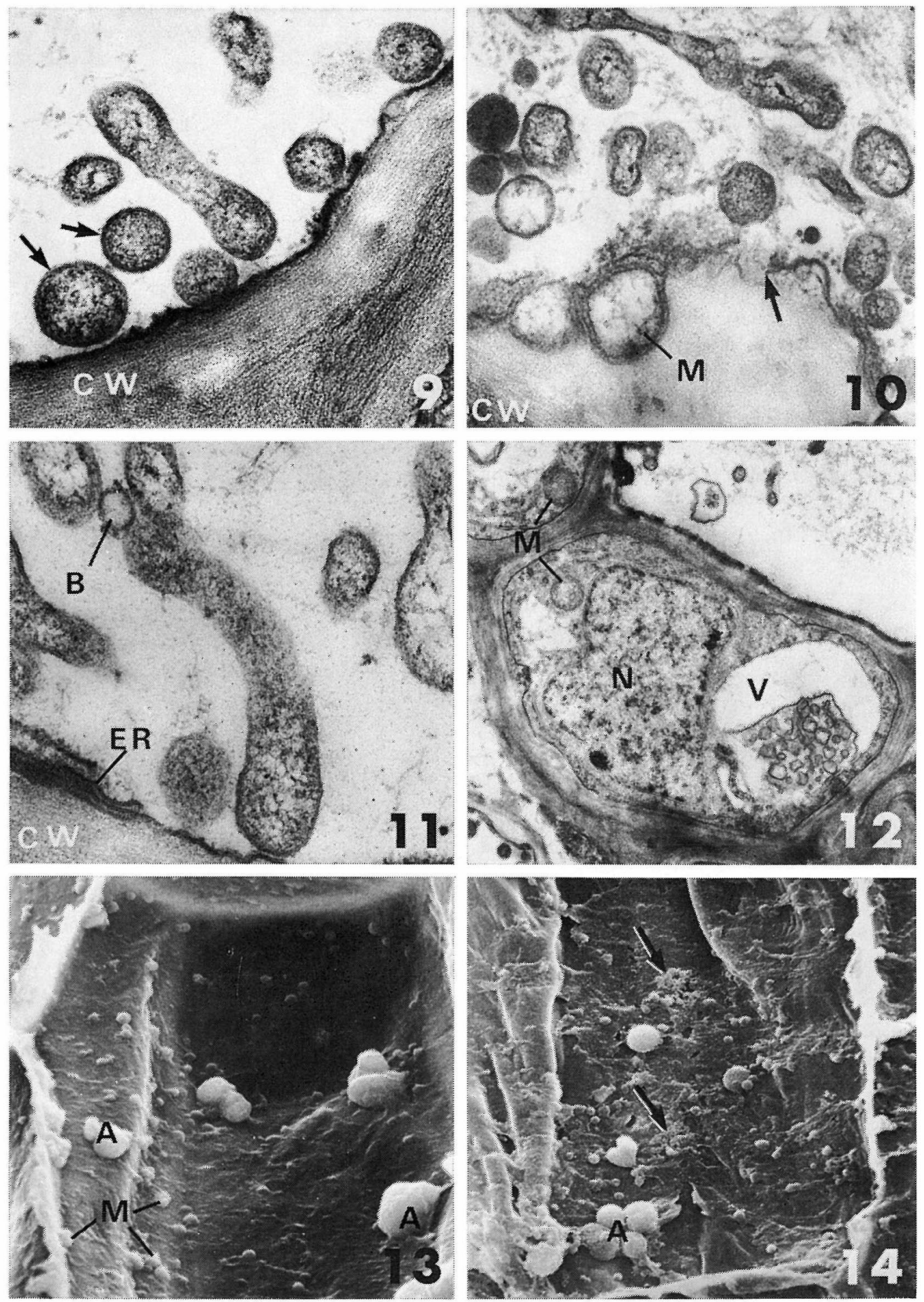

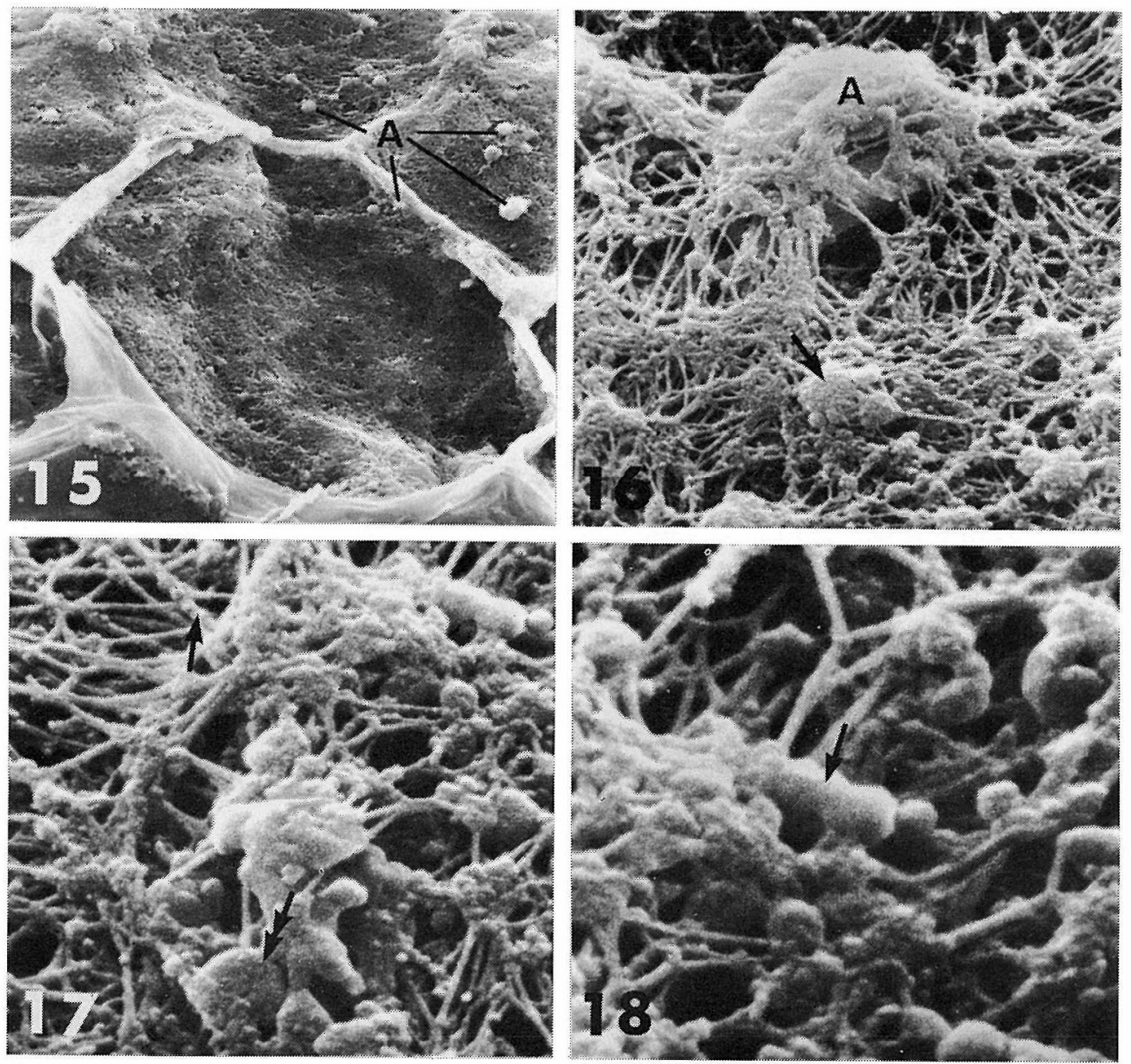

7.

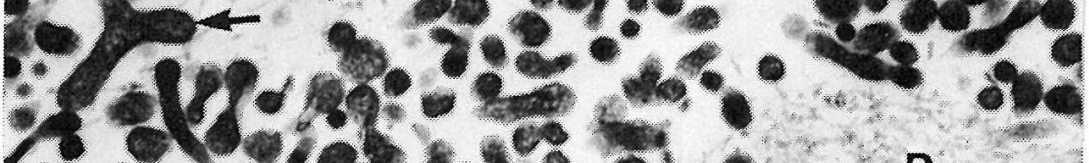
2.0sosen: $\mathrm{Pp}_{\mathrm{p}}$ s.6. 18.24 is.

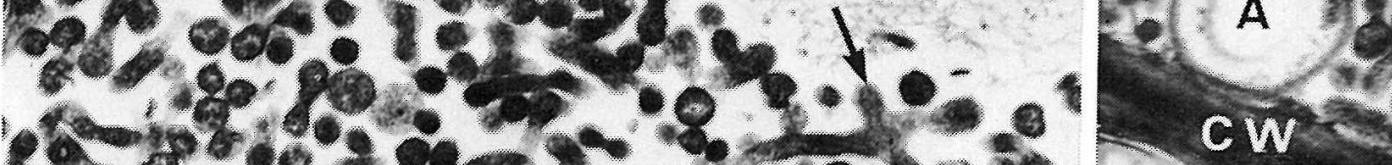

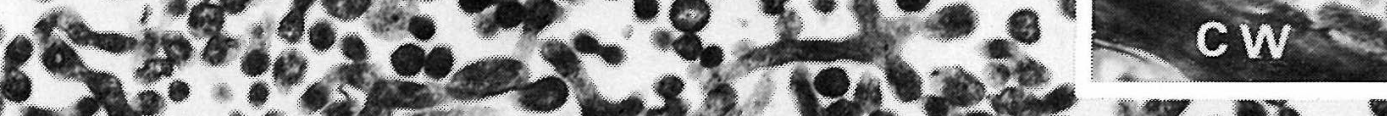

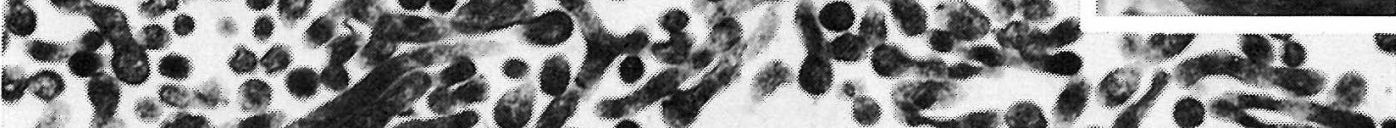

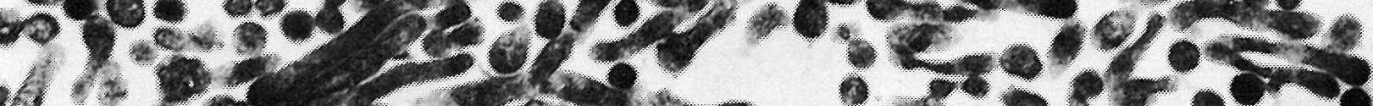

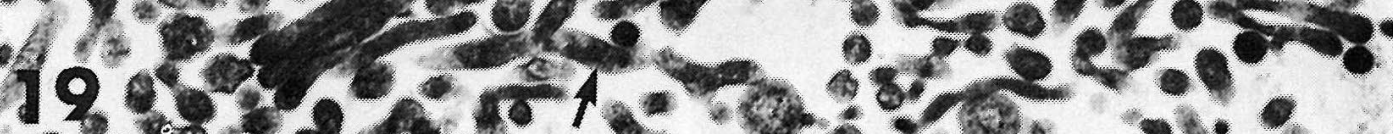

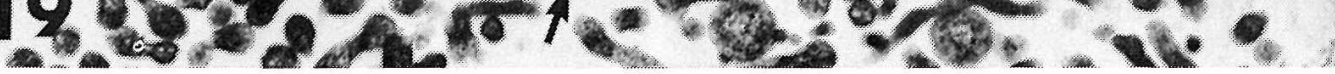



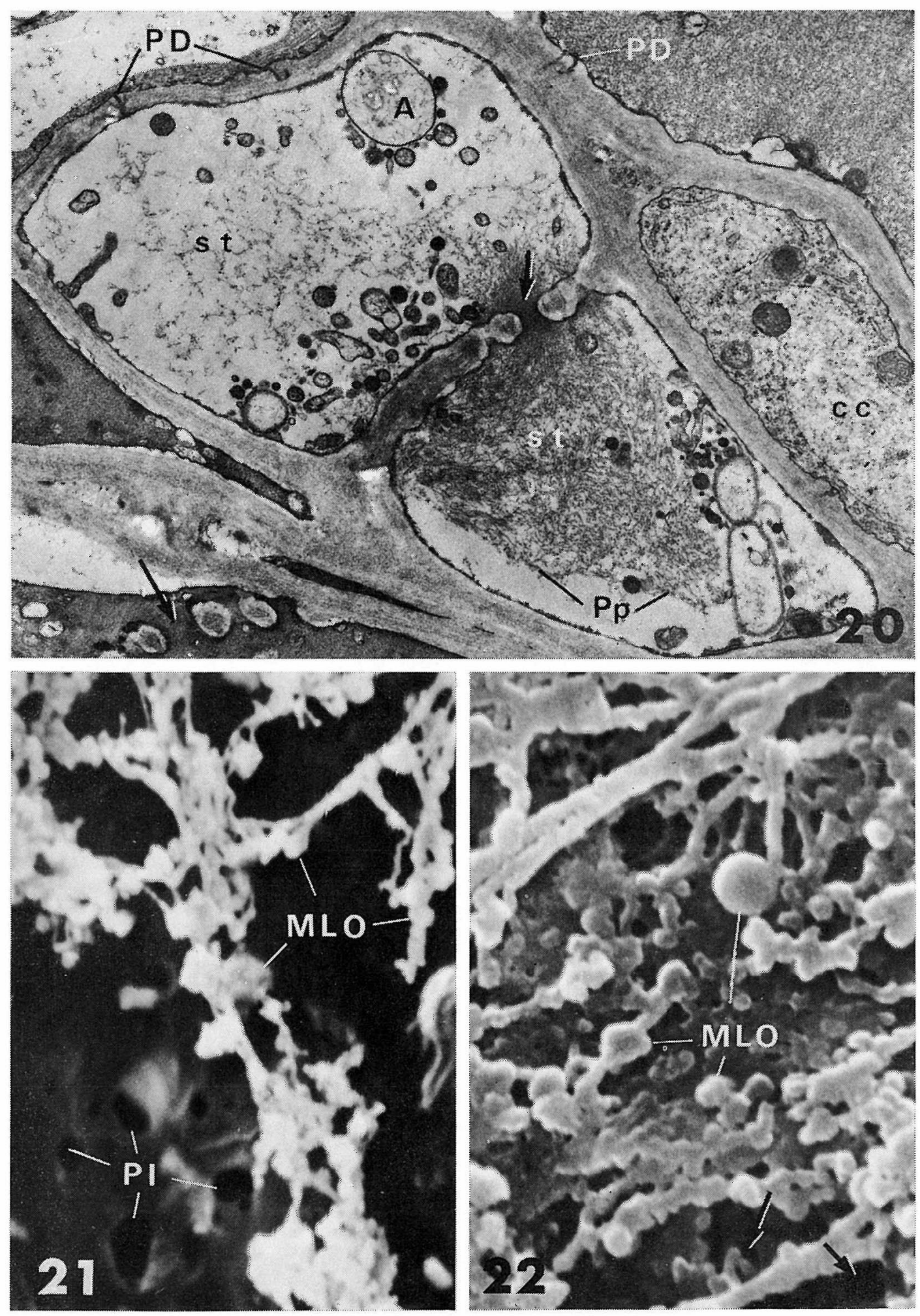